\title{
Control of fouling in the aquaculture of Fucus vesiculosus and Fucus serratus by regular desiccation
}

\author{
Rafael Meichssner ${ }^{1,2}$ (D) Nadja Stegmann ${ }^{1} \cdot$ Anna-Sarah Cosin ${ }^{1} \cdot$ Dagobert Sachs $^{1} \cdot$ Matthias Bressan $^{2}$. \\ Henriette Marx ${ }^{1} \cdot$ Peter Krost $^{2} \cdot$ Rüdiger Schulz ${ }^{1}$
}

Received: 26 May 2020 / Revised and accepted: 22 September 2020 / Published online: 7 October 2020

(C) The Author(s) 2020

\begin{abstract}
Fouling is a major problem in seaweed aquaculture and one of the main obstacles during the domestication process for new culture species. During first attempts to cultivate Fucus vesiculosus and Fucus serratus in the Kiel fjord (Western Baltic Sea), fouling by the epizoans Electra pilosa, Mytilus sp., and Amphibalanus improvisus rendered the production of marketable biomass impossible. This study tested (1) if regular desiccation by air exposure is effective in decreasing the abundance and size of foulers and (2) if and how regular desiccation affects the growth performance of the cultivated Fucus thalli. For this purpose, thalli of $F$. vesiculosus and $F$. serratus were cultivated freely floating in baskets directly deployed in the fjord and desiccated to defined percentages of the wet weight (ww) by air exposure. The treatments comprised controls and desiccations of different intensities (from 90 to $40 \%$ of ww) and at different frequencies $\left(1 \times\right.$ week $^{-1}, 3 \times$ week $\left.^{-1}\right)$. Growth rates of both Fucus species were not or only slightly reduced by the desiccation treatments. The final harvested biomass of $F$. vesiculosus under frequent mild desiccations ( $3 \times$ week $^{-1}$ to $80 \%$ of ww) was even higher than the biomass of undesiccated controls. The size of the epizoans E. pilosa and A. improvisus was significantly reduced by the desiccation treatments and the abundance of all epizoan species was drastically reduced by the desiccation regimes. Frequent mild desiccations (F. vesiculosus: $3 \times$ week $^{-1}$ to $80 \%$ of ww, F. serratus: $3 \times$ week $^{-1}$ to $90 \%$ of ww) proved to be most effective and decreased the epizoan ww share of the total harvest from $13.0 \pm 4.8 \%$ in the control to $1.8 \pm 0.2 \%$ for $F$. vesiculosus and from $19.1 \pm 2.7$ to $1.0 \pm 0.1 \%$ for $F$. serratus. Thus, desiccation seems to be an effective measure for the production of clean Fucus biomass in culture which is necessary for further valorization. A technical solution for the implementation of this procedure in large-scale cultures remains to be developed.
\end{abstract}

Keywords Fucus vesiculosus $\cdot$ Fucus serratus $\cdot$ Phaeophyceae $\cdot$ Aquaculture $\cdot$ Fouling $\cdot$ Epizoans $\cdot$ Desiccation $\cdot$ Air exposure

\section{Introduction}

Seaweed cultivation has become a large industry in the course of the past decades having reached an annual worldwide harvest of about 30 million t wet weight (ww) in 2016 (FAO 2018a). However, one major impediment limiting quantity as well as quality of seaweed production is the overgrowth of the

Electronic supplementary material The online version of this article (https://doi.org/10.1007/s10811-020-02274-2) contains supplementary material, which is available to authorized users.

Rafael Meichssner

rafael.meichssner@crm-online.de; rmeichssner@bot.uni-kiel.de

1 Physiology and Biotechnology of the Plant Cell, Christian-Albrechts-University, Kiel, Germany

2 CRM (Coastal Research \& Management), Kiel, Germany cultivated biomass by epiphytic algae and sessile animals, generally referred to as biofouling (Wahl 1989; Bannister et al. 2019). Epiphytic algae (hereafter epiphytes) can be of different systematic origin (red, green and brown algae, cyanobacteria, diatoms, prasinophytes etc.) and can make up to $60 \%$ of the harvested biomass (Buschmann and Gomez 1993; Fletcher 1995; Hurtado et al. 2006). Sessile animals (hereafter epizoans) comprise e.g. hydrozoans, ascidians, bryozoans, and barnacles (Park and Hwang 2012; Førde et al. 2016; Bruhn et al. 2016; Rolin et al. 2017). Both epiphytes and epizoans limit the growth of the cultivated seaweeds by reduction of available light and the impairment of nutrient uptake through coverage of the seaweeds' surface (Sand-Jensen and Revsbech 1987; Wahl 1989; Rohde et al. 2008). Moreover, they lead to increased biomass losses due to an intensification of drag forces (Anderson and Martone 2014) and their presence significantly lower the quality of the produced biomass, especially if cultivated for food purposes (Bannister et al. 2019). Biofouling has not only been 
reported for established culture species like Pyropia sp./ Porphyra sp. (Kim et al. 2014), Kappaphycus alvarezii (Hayashi et al. 2010; Kasim et al. 2017), and Gracilarial Gracilariopsis sp. (Fletcher 1995) but is also a frequently encountered problem in species that undergo first cultivation trials or have just recently been used in commercial cultivation (Walls et al. 2017).

In 2015, an experimental cultivation of Fucus vesiculosus L. and Fucus serratus L. has been established at the Kiel fjord in the Western Baltic Sea. Hitherto, Fucus biomass has been harvested exclusively from wild stocks e.g. at the Atlantic coast of Ireland and France (Mac Monagail et al. 2017). However, at the German Baltic Sea coast, harvesting of wild Fucus biomass for commercial purposes is prohibited (Bundesamt für Naturschutz 2013) due to dramatic stock declines in the twentieth century (Kautsky et al. 1986; Torn et al. 2006; Rohde et al. 2008). Consequently, aquaculture is the only means to sustainably produce Fucus biomass in Germany. A local production is desired, because "regionality" is a valuable claim for organic cosmetics and food supplements, the two main target markets for Fucus biomass (L. Piker, pers. comm.). The development of a culture method could also encourage the cultivation of this genus in other countries, which might become necessary as the market pull is expected to increase (Cherry et al. 2019). To our knowledge, the experiments in the Kiel fjord are among the first trials to cultivate Fucus species for commercial purposes (but see FAO 2018b; Haglund and Pedersen 1988).

The two target species (F. vesiculosus, F. serratus) are cultivated as freely floating thalli detached from substrate (Meichssner et al. in prep.), floating in net cages or plastic baskets. From the beginning, fouling, especially by epizoans, appeared to be one of the major challenges of this cultivation technique. The cultivated thalli showed a high degree of colonization by barnacles (Amphibalanus improvisus), blue mussels (Mytilus edulis/Mytilus trossulus), and bryozoans (Electra pilosa) in contrast to thalli in local field populations, which show only little colonization by epizoans (Rickert et al. 2015). An effective measure to reduce fouling will thus be crucial for the successful long-term implementation of this cultivation method. Means to prevent fouling in seaweed aquaculture are for example removal by hand, which is only possible if labor costs are low (Fletcher 1995). Secondly, growing and harvesting seasons can be planned in order to avoid the spore/ larval fall of epiphytes/epizoans (Anderson et al. 1996). A third method, which is applied in Pyropia sp./Porphyra sp. culture in Japan, is regular air exposure of the cultivated biomass (Kim et al. 2017). The targeted culture species is able to grow under temporarily aerated conditions, while the settling larvae/germlings of fouling species do not survive this treatment resulting in a strongly reduced amount of epibionts on the cultivated thalli and the cultivation ropes (Mumford and Miura 1988).
Both Fucus species cultivated in the experimental farm are able to survive temporal air exposure and desiccation, which enables them to colonize intertidal habitats (e.g. Schonbeck and Norton 1978; Dring and Brown 1982). Among the encountered foulers, A. improvisus and Mytilus sp. are also able to withstand desiccation and colonize temporally emerged locations (Barnes and Barnes 1957; Luther 1987; Buschbaum and Saier 2001); however, both species do not occur as far up the shore as F. vesiculosus in the Baltic Sea (own observation). Electra pilosa is not found at temporally air exposed locations in the Baltic Sea at all (own observation). Consequently, we hypothesized that all major fouling organisms observed in the experimental cultures are potentially less desiccation resistant than cultivated Fucus biomass. Therefore, regular air exposure (i.e. desiccation) of the cultivated biomass might be an effective method to reduce the abundance of these foulers in the cultures. As a complementary effect, we expected the size of already settled foulers to be affected by such a treatment, because times of emersion cannot be used for filter-feeding.

A pre-experiment in 2018 already revealed a strongly reducing effect of regular desiccation on the abundance of A. improvisus on cultivated Fucus thalli; however, desiccation was only performed once a week. As larvae and early settlement stages of the epizoans are often more sensitive to desiccation than adult individuals (Foster 1971a; Jenewein and Gosselin 2013), we expected more frequent desiccations to be even more effective, because larvae would experience the treatment early after settlement.

The aim of this study was (1) to test if regular desiccation by air exposure reduces the abundance and size of fouling organisms on the cultivated biomass and (2) to evaluate the effect of regular desiccation on the growth performance of the cultivated Fucus species. Different degrees of desiccation were compared as well as different desiccation frequencies. The aim was to find an optimal desiccation regime enabling the production of biomass ready for market demands.

\section{Material and methods}

\section{Location and timeframe of the experiment}

The experiment was located at premises of the Kieler Meeresfarm $\mathrm{GmbH} \& \mathrm{Co} . \mathrm{KG}$ in the northwestern part of the Kiel fjord in the Western Baltic Sea (54.381975 N; 10.162034 E). It was performed from 06 May 2019 to 31 July 2019. A pre-experiment in 2018 had shown that this is the season of highest larval pressure, which was confirmed by a weekly quantification of Mytilus sp. larvae in the water column ca. $1 \mathrm{~km}$ from the experiment site (P. Krost, pers. comm.). The onset of the larval fall at the beginning of July allowed to test the effect of desiccation 
on Fucus growth rates before the occurrence of epizoans on the thalli, especially since A. improvisus and E. pilosa did not occur before that time either (Fig. 1). Moreover, former experiments had shown that growth rates of cultivated Fucus thalli are highest during this season (see also Lehvo et al. 2001).

\section{Algal material}

Fucus vesiculosus and F. serratus individuals were collected from the field at 05 May 2019. Fucus vesiculosus was collected in Kiel/Holtenau (54.368966 N; 10.154112 E) and F. serratus in Bülk (54.455146 N; $10.198858 \mathrm{E})$. Both were transported in seawater to premises close to the cultivation site where they were stored overnight in seawater. The following day, vegetative thallus apices (hereafter "thalli") were cut from the collected individuals for use in the experiment. The thalli had lengths of 3-10 cm for $F$. vesiculosus and $5-15 \mathrm{~cm}$ for $F$. serratus.

\section{Cultivation containers}

The thalli were cultivated in black plastic baskets (BAUHAUS; Oase Pflanzkorb; edge length: $28 \mathrm{~cm}$; volume: $14 \mathrm{~L}$ ). The baskets had holes of ca. $0.3 \times 0.3 \mathrm{~cm}$ at all sides allowing for the permanent inflow of surrounding seawater. Each basket was covered with a transparent plastic mesh to prevent loss of thalli. The baskets were arranged in packages of eight, leaving an empty space in the center (Fig. 2a). The basket packages were kept floating in the fjord by attachment to polyethylene foam pipe insulations. The experimental culture was protected from wave destruction by a pipe frame $(2 \times 4 \mathrm{~m}$, Fig. $2 \mathrm{a})$.

Three packages of eight baskets were used for the experiment. Thus, eight experimental groups could be tested, each being represented once in each of the three packages $(n=3)$.

For $F$. vesiculosus, five treatments were applied:

- Control (no desiccation)

\section{Experimental time frame and occurrence of bivalve larvae}

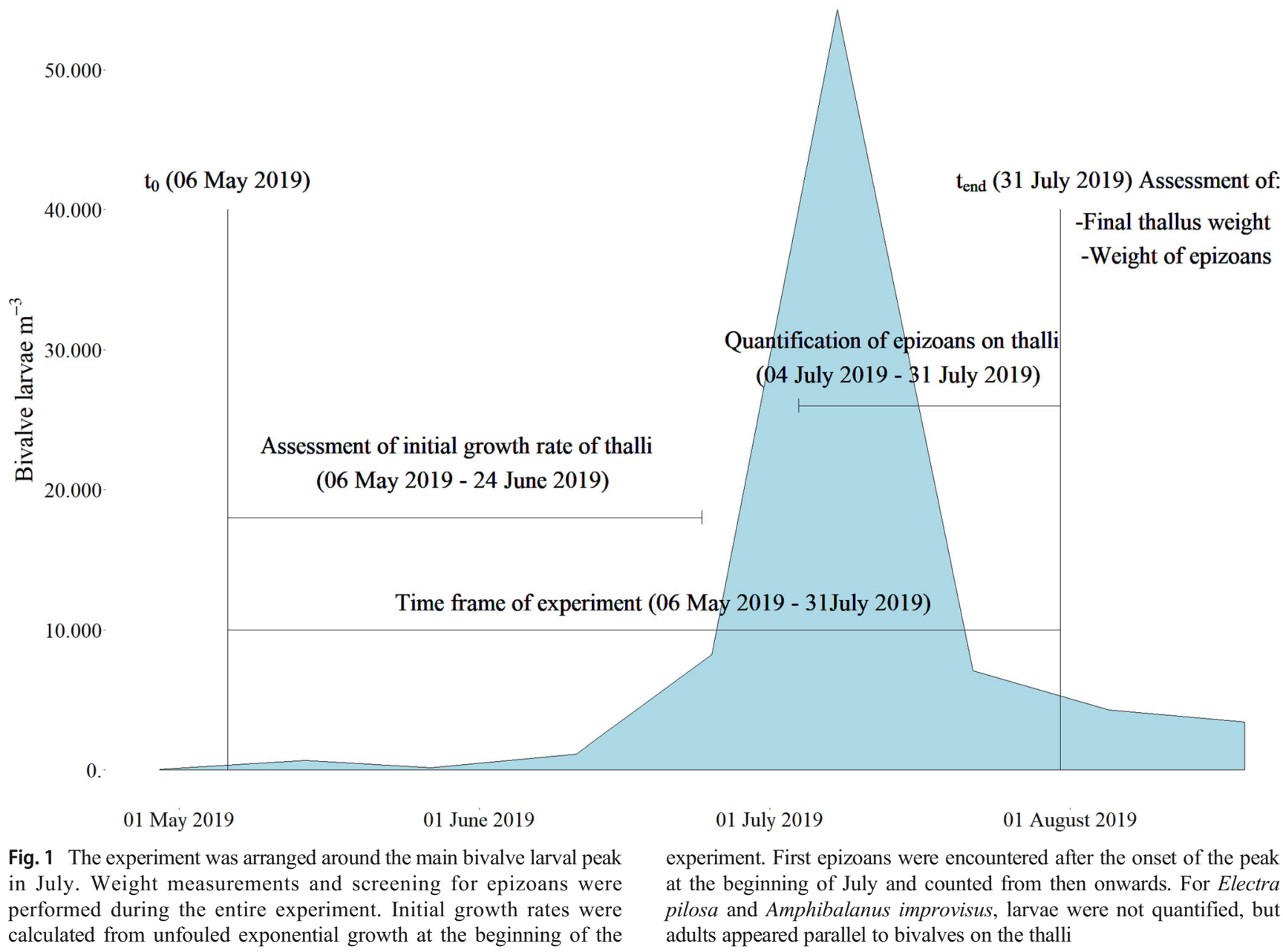




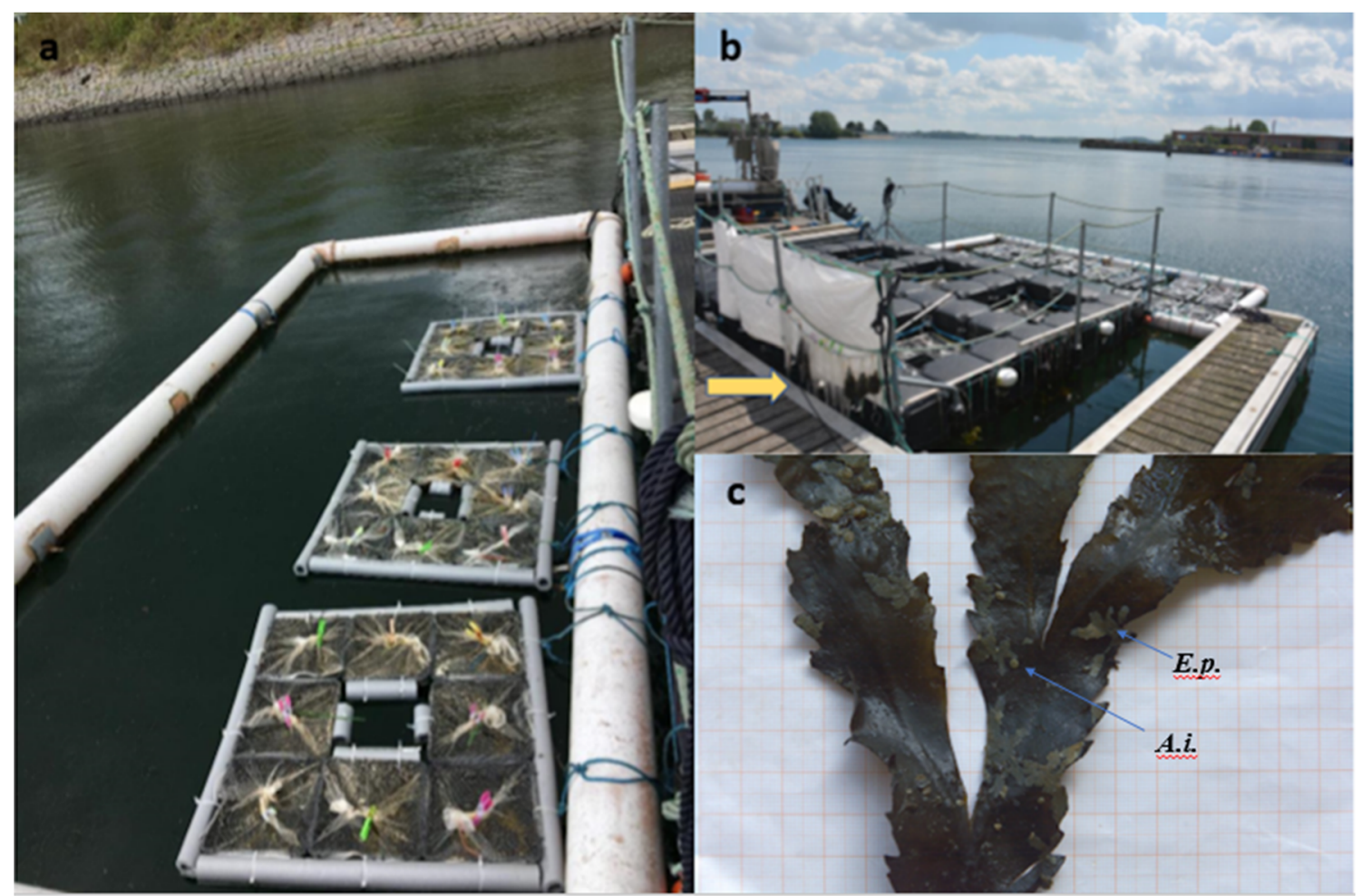

Fig. 2 a Cultivation baskets were arranged in three packages of eight baskets each, allowing for eight treatments with three replicates. b The cultivation site was located at the northwestern part of the Kiel fjord; thalli were desiccated in plastic nettings in the shade of an awning (arrow). c Fouled $F$. serratus thallus from control treatment with Electra pilosa and Amphibalanus improvisus
- One desiccation to $80 \%$ of ww per week (in the following: $1 \times 80 \%$ )

- Three desiccations to $80 \%$ of ww per week (in the following: $3 \times 80 \%$ )

- One desiccation to $60 \%$ of ww per week (in the following: $1 \times 60 \%$ )

- One desiccation to $40 \%$ of ww per week (in the following: $1 \times 40 \%$ )

For F. serratus, three treatments were applied:

- Control (no desiccation)

- One desiccation to $80 \%$ of ww per week (in the following: $1 \times 80 \%$ )

- One desiccation to $60 \%$ of ww per week; from 27.05 . onwards: three desiccations to $90 \%$ of ww per week (in the following: $3 \times 90 \%$ )

The treatment $1 \times 60 \%$ of $F$. serratus was replaced after 3 weeks (27 May 2019) by $3 \times 90 \%$, because the thalli were already degrading due to the treatment. The degradation was first visible by a browning of the thallus margins and proceeded with a slow dissolution of the entire thallus. As first epizoans were detected at the beginning of July, a treatment change at this early stage of the experiment was considered possible. The replacing treatment was started at 27 May 2019 using newly collected thalli with the same average weight as the other two $F$. serratus treatments. The treatment $3 \times 90 \%$ was chosen instead of $3 \times 80 \%$, because in pre-experiments, $F$. serratus had been proven to be very sensitive towards desiccation. A direct comparability to the $F$. vesiculosus treatments was lost by this change; however, it was rather the aim to find desiccation regimes suitable for $F$. serratus than to allow for a direct comparison to $F$. vesiculosus. As a consequence, only the controls of the two species were compared directly (see "Statistical analysis").

\section{Cultivation and measurement of thallus growth}

The thalli were freely floating in the baskets without any attachment. The cultivation was started with $20 \mathrm{~g}$ of thalli per basket. Thallus growth was assessed weekly by weight measurements. Before weighing, the thalli were dried with a salad spinner for $15 \mathrm{~s}$. Weighing was performed with a lab scale (Kern EMB 1200) under wind protected conditions. The relative daily growth rate was calculated using the following formula:

$\operatorname{DGR}\left(\%\right.$ day $\left.^{-1}\right)=\left(\ln \left(\mathrm{W}_{\mathrm{t}} / \mathrm{W}_{0}\right) / \mathrm{t}\right) * 100$

where $D G R$ is the daily growth rate in percent, $W_{t}$ is the 
weight at a given date, $W_{0}$ is the weight at the beginning of the experiment, and $t$ is the number of days between $W_{0}$ and $W_{t}$. DGR was calculated until 24 June 2019 (Fig. 3a), because growth ceased to be exponential after that date for most experimental units, and there was no effect of epizoans on the growth rate up to this date (Fig. 1).

\section{Desiccation treatment}

For desiccation, all thalli of one basket were filled in a plastic netting of known weight. The filled netting was then dipped in seawater for $2 \mathrm{~s}$ and hung on a rope for the further drying procedure. The rope was shaded by a white plastic awning to avoid direct sun exposure of the drying thalli. This was done because direct sun had led to very unequal drying of the biomass in a pre-experiment. After letting the thalli drain for $5 \mathrm{~min}$, the weight of the
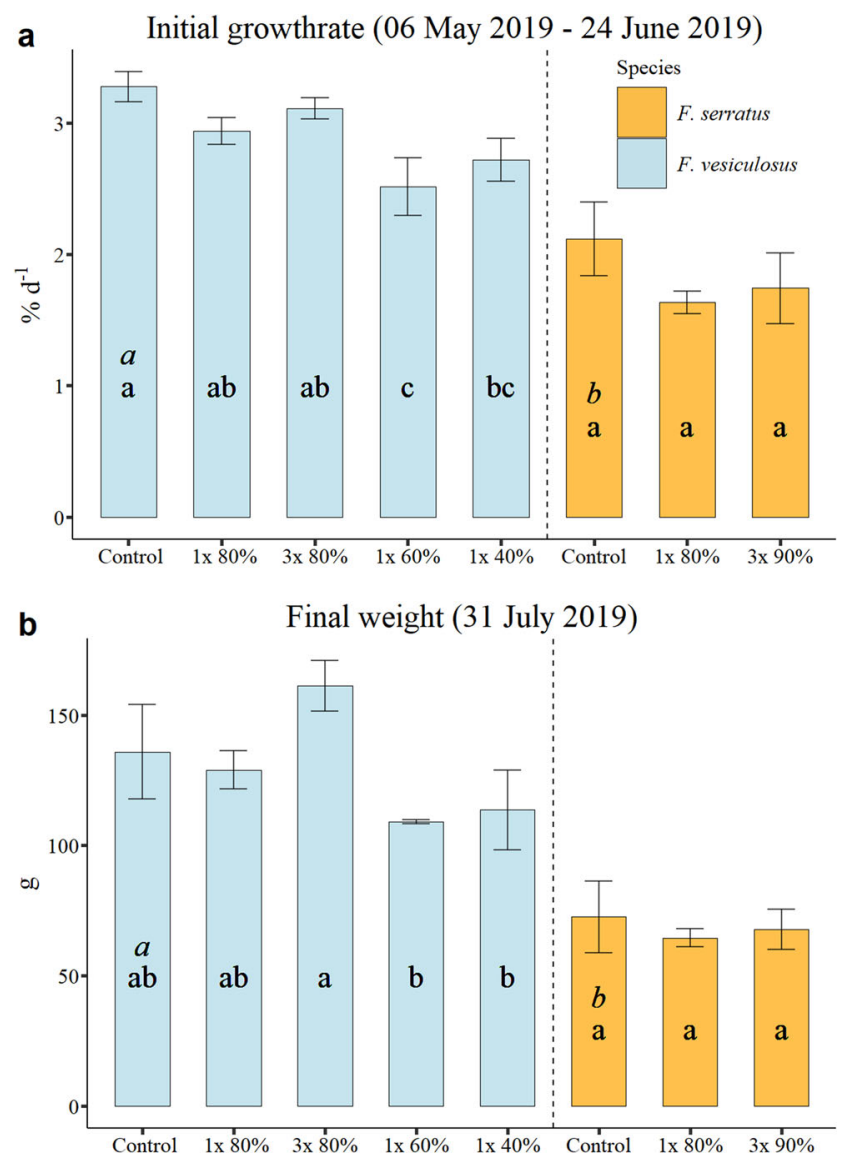

Fig. 3 a Initial growth rates of Fucus vesiculosus and F. serratus thalli during exponential growth phase at the beginning of the experiment when no epizoans were present, calculated as percent ww increase per day. b Final weight after 86 experimental days (starting weight: $20 \mathrm{~g}$ ), calculated as measured final weight minus calculated weight of epizoans. For both graphs, treatments were compared statistically within species (one-way ANOVA, roman letters). For species comparison, controls were compared by Welch's $t$ test (italic letters). Error bars indicate standard deviation, $n=3$, except for final weight of $F$. vesiculosus $1 \times 60 \%$, where $n=2$ netting including the thalli was measured. The weight of the netting was subtracted in order to calculate the ww of the thalli. After that, the thalli were regularly weighed until the desired percentage of the ww $(90,80,60$, or $40 \%$ ) was achieved. The thalli of all experimental units including the controls were filled in nettings three times a week to control for handling effects.

\section{Quantification of epizoans}

The epizoans were counted weekly by screening every single thallus. The first epizoans were encountered at the beginning of July (Fig. 1) which coincided with the bivalve larval fall. A list of all encountered species is given in Table 1. Clava multicornis was only encountered on a few thalli and hence not included in the analysis. For Electra pilosa, the number of colonies was assessed. All bivalves were combined in one group, because it was impossible to correctly distinguish the young stages. The group was dominated by Mytilus edulis/M. trossulus, both of which occur at the location and hybridize strongly (Utermann et al. 2018). Mya arenaria was only encountered occasionally and represented only a very small portion of the bivalve biomass. Mya arenaria individuals larger than $4 \mathrm{~mm}$ were never encountered, as they probably died due to the lack of sandy habitat. Bivalves were counted at sizes > $0.5 \mathrm{~mm}$. Amphibalanus improvisus was counted if identifiable with the naked eye (diameter ca. $0.7 \mathrm{~mm}$ ). At the end of the experiment (31 July 2019), ten individuals/ colonies of each group were scraped from the thalli of one replicate of each treatment except for E. pilosa as ten or more colonies were found only in $F$. vesiculosus control, $F$. serratus control, and $F$. serratus $1 \times 80 \%$ (F. vesiculosus $3 \times 80 \%: n=2,1 \times 60 \%: n=5,1 \times 40 \%$ : $n=0, F$. serratus $3 \times 90 \%: n=7)$. They were weighed with a fine scale and the average weight of the epizoans was calculated for each treatment individually, because they appeared to have different weights in the different treatments (Fig. 4).

\section{Calculation of further response variables}

Using these average weights of each single treatment, the measured weights of the fouled thalli were corrected by the weights of the counted epizoans, resulting in epizoan-free Fucus weights for 31 July 2019 (Fig. 3b). Using these epizoan-free weights, it was possible to normalize the epizoan counts of 31 July 2019 by 100 g of pure Fucus biomass (Fig. $5 \mathrm{a}-\mathrm{c}$ ) and calculate the epizoan share of the final harvest (Fig. 5d).

Fucus growth curves over the entire experimental time (calculated as epizoan-free, using the epizoan weight data of 
Table 1 Epizoan species encountered in the timeframe of the experiment

\begin{tabular}{ll}
\hline Species found on the cultured Fucus biomass & Phylum, class \\
\hline Clava multicornis Forsskal, 1775 & Cnidaria, Hydrozoa \\
Electra pilosa Linnaeus, 1767 & Bryozoa, Gymnolaemata \\
Mytilus edulis Linnaeus, 1758 & Mollusca, Bivalvia \\
Mytilus trossulus Gould, 1850 & Mollusca, Bivalvia \\
Mya arenaria Linnaeus, 1758 & Mollusca, Bivalvia \\
Amphibalanus improvisus Darwin, 1854 & Arthropoda (Crustacea), Maxillopoda (Cirripedia) \\
\hline
\end{tabular}

31 July 2019) and normalized epizoan abundances over time are depicted in the supplementary material (Figs. S3 and S4).

\section{Environmental data}

Irradiance was measured as photon flux density (PFD) in the PAR range in the botanical garden of the Christian-Albrecht University (4.87 km from the experimental site) in parallel to the experiment. For this purpose, a photodiode was placed at a height of $10 \mathrm{~cm}$ above the ground at an unshaded location. The photodiode was calibrated against a quantum sensor (LI190, LI-COR, USA) and PFD was continuously measured every second with averages being stored for $10 \mathrm{~min}$ intervals and light sums being calculated for each day (method identical to Pescheck and Bilger 2019). The reduction of PFD within the cultivation baskets caused by the plastic mesh was determined at seven positions within a sample basket by a quantum sensor (LI-250A, LI-COR, USA). New mesh reduced the incoming irradiance by $4 \pm 2 \%$ and mesh colonized by a microalgal biofilm (typically occurring after 3-4 weeks of cultivation) by $12 \pm 4 \%$. The water temperature within the black cultivation baskets was recorded every 30 min using a Hobo $\odot$ pendant datalogger. Irradiance and water temperature are depicted in the supplementary material (Figs. S1 and S2).

\section{Statistical analysis}

Statistical analysis was performed with $\mathrm{R}$ (R Core Team 2013). The data were square root transformed for analysis. The five groups of $F$. vesiculosus and the three groups of $F$. serratus were compared individually by one-way ANOVA and Tukey's HSD as post hoc test for all measured parameters (initial Fucus growth rate; Fucus final weight (31 July 2019, epizoan-free); epizoan weight; epizoan abundance; epizoan share of final harvest). In addition, the control groups of the two species were compared by Welch's $t$ test. For the group $F$. vesiculosus $1 \times 60 \%$, one replicate was lost at the end of the experiment; therefore, the Fucus final weight at 31 July 2019, epizoan abundance, and epizoan share of final harvest had to be analyzed with two replicates for this group. For the analysis of the weights of E. pilosa, some treatments had reduced numbers of replicates due to the low numbers of colonies found (see "Quantification of epizoans"). Normality of residuals and homogeneity of variances were tested by Shapiro-Wilk's test and Fligner's test, respectively. In five out of 27 analyses (weight of A. improvisus on $F$. vesiculosus and $F$. serratus groups; weight of Bivalvia on $F$. vesiculosus and $F$. serratus groups; $F$. vesiculosus control vs. F. serratus control for weight of Bivalvia), the assumptions were not fulfilled due to non-normal residuals. In the four cases of multiple group comparisons, Kruskal-Wallis test with a post hoc Dunn's test was used, while a WilcoxonMann-Whitney test was used for the one case of a pair-wise comparison. $p$ values below 0.05 were considered statistically significant.

\section{Results}

\section{Growth of the cultivated Fucus biomass}

The Fucus thalli of all treatments showed considerable growth during the experiment. Differences between the two Fucus species and among the treatment groups will be explained in detail hereafter.

\section{Initial growth rate (06 May 2019-24 June 2019)}

The control thalli of $F$. vesiculosus showed a significantly higher initial growth rate $\left(3.27 \pm 0.12 \%\right.$ day $\left.^{-1}\right)$ than the control thalli of $F$. serratus $\left(2.12 \pm 0.28 \%\right.$ day $\left.^{-1}\right)(t$ test: $p=$ 0.0169 , df $=2.4162$, Fig. $3 \mathrm{a}$ ), both untreated controls ( $F$. vesiculosus, $F$. serratus) showed higher initial growth rates than the desiccation treatments, respectively.

For $F$. vesiculosus, mild desiccations $(1 \times 80 \%, 3 \times 80 \%)$ reduced the growth rate slightly (to $2.94 \pm 0.10 \%$ day $^{-1}$ and $3.11 \pm 0.08 \%$ day $^{-1}$ ) but not statistically significant compared with the controls. Harsh desiccations $(1 \times 60 \%, 1 \times 40 \%)$ led to a slightly stronger and statistically significant reduction of the growth rates (to $2.51 \pm 0.22 \%$ day $^{-1}$ and $2.71 \pm 0.16 \%$ day $^{-1}$, ANOVA: $p=0.0007, \mathrm{df}=4$, Tukey's HSD: $p=$ 0.0078 and 0.0007$)$.

For $F$. serratus, mild desiccations $(1 \times 80 \%, 3 \times 90 \%)$ resulted in reduced growth rates $\left(1.63 \pm 0.08 \%\right.$ day $^{-1}$ 
and $1.74 \pm 0.27 \%$ day $^{-1}$ ), the difference was, however, not statistically significant.

Among the mildly desiccated treatments, frequency of desiccation exerted in neither of the species a significant effect.

Fucus serratus was more susceptible to desiccation showing similar reductions of the growth performance at mild desiccation regimes as $F$. vesiculosus showed at strong desiccation regimes. As mentioned before, desiccation to $60 \%$ had led to degradation of the cultivated $F$. serratus thalli, whereas $F$. vesiculosus grew well at this treatment and even at desiccation to $40 \%$ of ww.

\section{Final weight (31 July 2019)}

The average epizoan-free weight of the Fucus biomass at the end of the experiment (Fig. 3b) ranged between 109 and $161 \mathrm{~g}$ for $F$. vesiculosus and 65 and $73 \mathrm{~g}$ for $F$. serratus (averaged over replicates), thus the absolute growth within the experimental time ranged between 378 and $706 \%$ for $F$. vesiculosus and between 223 and $264 \%$ for $F$. serratus. The controls of $F$. serratus showed a significantly lower final weight than the $F$. vesiculosus controls (average absolute difference: $47 \%, t$ test: $p=0.0088, \mathrm{df}=3.9678$ ).

For $F$. vesiculosus, there was no significant difference between the single mild desiccations $(1 \times 80 \%)$ and the control; however, the $3 \times 80 \%$ treatment on average led to a $19 \%$ higher final weight than the control (non-significant, Tukey's HSD: $p=0.47$ ). This was not expected, as the highest initial growth rate was found in the control. The effect of harsh desiccations was similar to the effect observed in the initial growth rates but statistically not significant. Similarly, for $F$. serratus, the differences in initial growth rates between the control and the desiccation treatments almost disappeared over the duration of the experiment.

\section{Fouling}

An intense colonization of the cultivated thalli by E. pilosa, bivalves, and $A$. improvisus occurred during the experiment from the beginning of July. However, the desiccation treatments led to significant reductions of the average individual weight as well as the abundance of epizoans compared with untreated control thalli. The details will be explained in the following.

\section{Weight of epizoans}

The weight data of all epizoans showed a huge variability reflecting the different sizes of the measured individuals. Among the groups of one Fucus species, the maximum measured weights always occurred on control thalli.

\section{Electra pilosa}

There was no significant difference in the weight of $E$. pilosa colonies between the controls of $F$. vesiculosus and $F$. serratus $\left(0.08\right.$ and 0.05 g colony $^{-1}, t$ test: $p=0.24$, Fig. 4a). Among the F. vesiculosus groups, E. pilosa colonies were significantly larger on control than on desiccated thalli, whereas there was no significant difference among desiccation treatments. A desiccated colony (averaged over all desiccation treatments) was $85 \%$ smaller than a colony on a control thallus. This trend was already observed during the experiment: the colonies found on the control thalli had sizes of up to several $\mathrm{cm}^{2}$ while those on desiccated thalli sometimes consisted only of few $(<$ $50)$ individual zooids. The same pattern was found for $F$. serratus.

On both Fucus species, the colonies on thalli desiccated three times a week were the smallest. For F. vesiculosus thalli desiccated once a week to $40 \%$, no weights could be determined, because the thalli were completely bryozoan-free.

\section{Bivalves}

There was no statistically significant difference in the weight of bivalves between the control thalli of the two Fucus species (averages: F. vesiculosus: 0.017 g, F. serratus: 0.012 g, Fig. 4b). Among the groups, there was no significant difference in the weight of bivalves, but the untreated controls bore by trend heavier bivalves than the desiccated thalli ( $F$. vesiculosus: control $53 \%$ heavier than average of desiccation treatments; $F$. serratus: control treatment $59 \%$ heavier than average of desiccation treatments). There was also a tendency towards smaller bivalves on frequently desiccated thalli compared with thalli desiccated only once a week; however, this trend was also insignificant in both species.

\section{Amphibalanus improvisus}

Amphibalanus improvisus individuals were significantly heavier on $F$. vesiculosus control thalli $(0.039 \pm 0.024 \mathrm{~g})$ than on $F$. serratus control thalli $(0.013 \pm 0.012 \mathrm{~g}, t$ test: $p=$ 0.0027, df = 16.507, Fig. 4c).

In $F$. vesiculosus, individuals on control thalli were on average $72 \%$ heavier than individuals of the desiccation treatments (Dunn's test between control and all desiccation treatments: $p<0.01$ ), whereas no significant differences were found among the desiccation treatments.

In F. serratus, the barnacles found on control thalli were on average $75 \%$ heavier than those on thalli of the $3 \times 90 \%$ treatment (Kruskal-Wallis test: $p=0.0013, \mathrm{df}=4$, post hoc Dunn's test: $p=0.013$, but there was no significant difference 

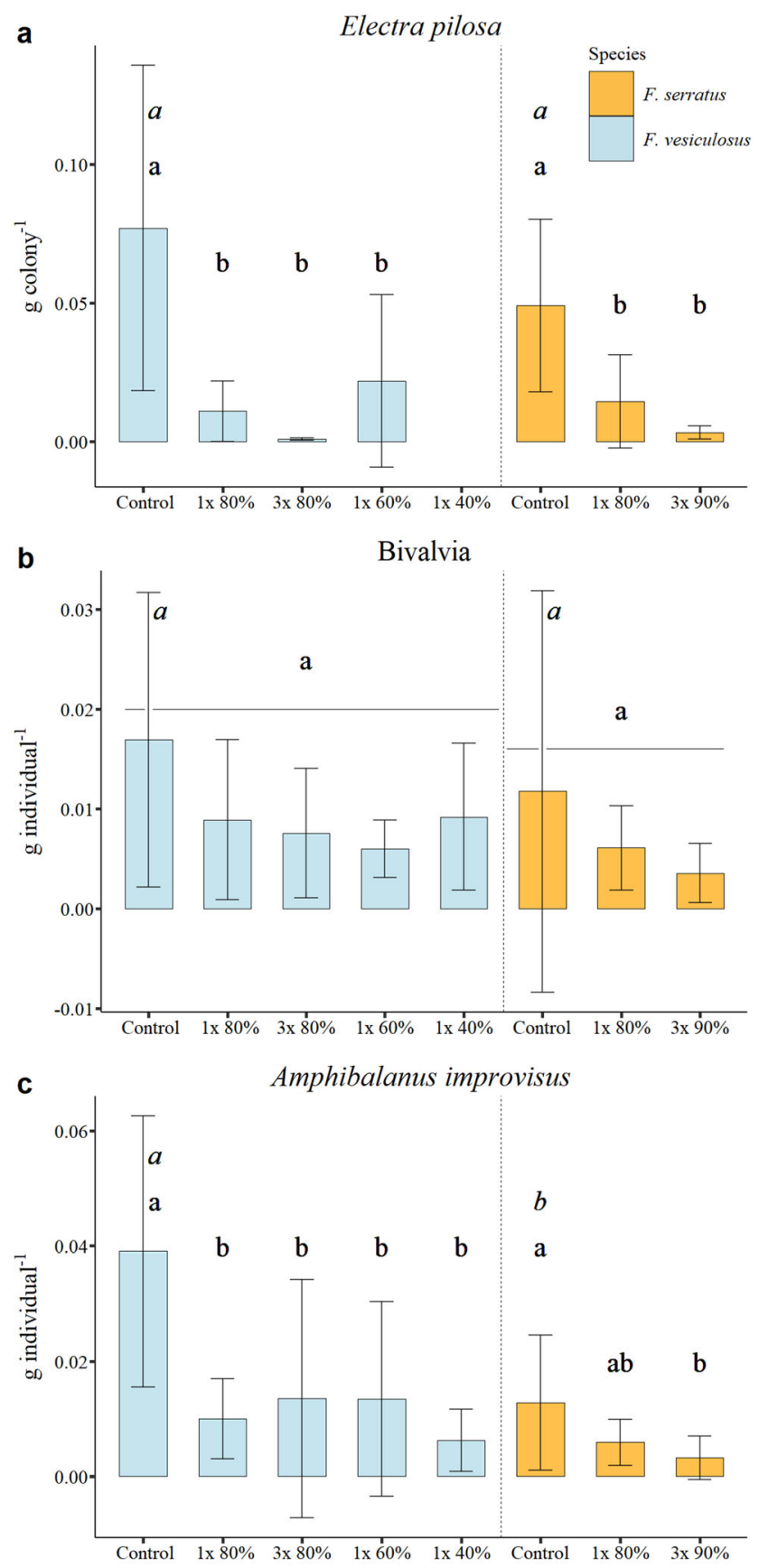

Fig. 4 a-c Weight of epizoans scraped from one replicate of each treatment at the end of the experiment (31 July 2019). Treatments were compared statistically within species (one-way ANOVA/Kruskal-Wallis test, roman letters). For species comparison, controls were compared by Welch's $t$ test/Wilcoxon-Mann-Whitney test (italic letters). Error bars indicate standard deviation, different letters indicate statistically significant differences, $n=10$, exceptions: $E$. pilosa: $F$. vesiculosus $3 \times 80 \%$ : $n=2,1 \times 60 \%: n=5,1 \times 40 \%: n=0, F$. serratus $3 \times 90 \%: n=7$. The exceptions were due to the low numbers of $E$. pilosa colonies found on the treated thalli

between the control and the $1 \times 80 \%$ treatment, although the averaged relative difference was $54 \%$.

\section{Epizoan abundance}

All epizoan species were most abundant on controls, except for A. improvisus on $F$. vesiculosus, where a similar number was found in the control and all treatments, except the $3 \times 80 \%$ treatment (Fig. $5 \mathrm{a}-\mathrm{c}$ ). However, the degree of reduction by the desiccation treatments varied among the epizoan species and will be explained in detail hereafter.

\section{Electra pilosa}

There was a significantly lower number of $E$. pilosa colonies per $100 \mathrm{~g}$ biomass on $F$. vesiculosus controls than on F. serratus controls $(38.8 \pm 22.5$ colonies vs. $211.6 \pm 13.9$ colonies; $t$ test: $p=0.0096, \mathrm{df}=2.2954$, Fig. 5a).

Among the $F$. vesiculosus groups, desiccation reduced the number of bryozoans drastically. Mild desiccations reduced the number significantly from $38.8 \pm 22.5$ to $7.6 \pm 4.9(1 \times$ $80 \%)$ and to $3.0 \pm 3.0(3 \times 80 \%)$ colonies $(100 \mathrm{~g} \text { seaweed })^{-1}$ (ANOVA: $p=0.0004, \mathrm{df}=4$, Tukey's HSD: $p=0.017$ and $0.003)$. The difference between one and three mild desiccations per week was statistically not significant. An even stronger effect exerted the harsh treatments on the number of bryozoans; in the $1 \times 60 \%$ treatment, only $0.5 \pm 0.7$ colonies were found, in the $1 \times 40 \%$ treatment not a single colony was found in any of the experimental units (Tukey's HSD: $p=0.0014$ and 0.0003 ).

For $F$. serratus, a similarly strong effect of the desiccation treatments was observed, the number of colonies was reduced from $211.6 \pm 13.9$ in the control to $18.0 \pm 3.2$ colonies in the $1 \times 80 \%$ treatment and $12.3 \pm 6.8$ in the $3 \times 90 \%$ treatment (ANOVA: $p=1.3^{*} 10^{-6}, \mathrm{df}=2$, Tukey's HSD: $p<0.0001$ in both cases).

\section{Bivalves}

The colonization by bivalves was fairly strong with at times more than 600 individuals $(100 \mathrm{~g} \text { seaweed })^{-1}$ (Fig. 5b). There was no significant difference between the $F$. vesiculosus control and the $F$. serratus control $(t$ test: $p=0.50$ ).

For $F$. vesiculosus, very harsh desiccations $(1 \times 40 \%)$ and frequent mild desiccations $(3 \times 80 \%)$ significantly reduced the number of bivalves from $462 \pm 153$ individuals in the control to $182 \pm 59$ individuals and to $214 \pm 39$ individuals, respectively (ANOVA: $p=0.0099, \mathrm{df}=4$, Tukey's HSD: $p=0.017$ and 0.043).

In $F$. serratus, desiccation produced similar effects (oneway ANOVA: $p=0.007, \mathrm{df}=2$ ). The number of bivalves was reduced from $553 \pm 150$ in the control to $318 \pm 65$ in the $1 \times$ $80 \%$ treatment and to $196 \pm 36$ individuals in the $3 \times 90 \%$ treatment (Tukey's HSD: $p=0.055$ and 0.005). 

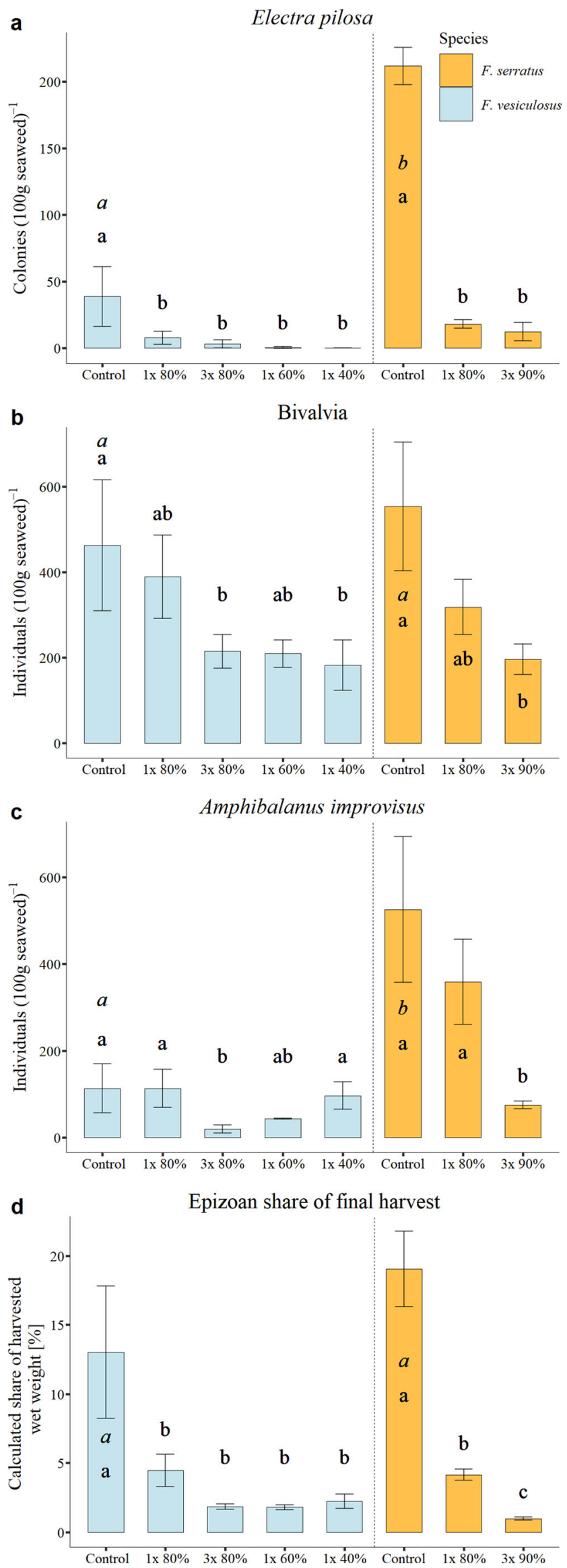

Fig. 5 a-c Number of epizoans per $100 \mathrm{~g}$ of Fucus biomass (calculated as epizoan-free) at the end of the experiment (31 July 2019). d Percentage of epizoan weight of total harvested weight at the end of the experiment (31 July 2019). For all graphs, treatments were compared statistically within species (one-way ANOVA, roman letters). For species comparison, the controls were compared by Welch's $t$ test (italic letters). Error bars indicate standard deviation, different letters indicate statistically significant differences, $n=3$, except for $F$. vesiculosus $1 \times 60 \%$, where $n=2$ for all graphs

\section{Amphibalanus improvisus}

Amphibalanus improvisus also appeared in high numbers, especially on $F$. serratus with an average of $526 \pm 68$ individuals (100 g seaweed) $)^{-1}$ found in the control (Fig. 5c). This was significantly more than on $F$. vesiculosus, where only $113 \pm$ 57 individuals were found ( $t$ test: $p=0.014$, $\mathrm{df}=3.4954$ ).

In $F$. vesiculosus as well as in $F$. serratus, only the frequent mild desiccations $(3 \times 80 \%, 3 \times 90 \%)$ led to a significant reduction of the number of barnacles in comparison to the controls, on average by $83 \%$ and $86 \%$, respectively. Infrequent treatments $(1 \times$ per week) were not effective, independent of the harshness of the desiccation.

\section{Epizoan share of final harvest}

The strong fouling intensity is apparent in the high weight percentage of epizoans in the untreated controls (F. vesiculosus: $13.0 \pm 4.8 \%$; F. serratus: $19.1 \pm 2.7 \%, t$ test: $p=0.155$, Fig. $5 d$ ). However, for both species, all desiccation treatments resulted in a significant reduction of this value (ANOVA: $F$. vesiculosus: $p=0.0001, \mathrm{df}=4, F$. serratus: $p=2.07 * 10^{-6}, \mathrm{df}=2$, Tukey's HSD: all $p$ values below $0.005)$, the frequent desiccation treatments $(3 \times 80 \%, 3 \times$ $90 \%$ ) being most effective resulting in only $1.8 \pm 0.2 \%$ in $F$. vesiculosus and $1.0 \pm 0.1 \%$ in $F$. serratus. For $F$. vesiculosus, there was no statistically significant difference among the desiccation treatments, whereas for F. serratus, the epizoan share of the $1 \times 80 \%$ treatment was significantly larger than the epizoan share of the $3 \times 90 \%$ treatment (Tukey's HSD: $p=0.0015)$.

\section{Discussion}

In this study, the question was raised if regular desiccation is effective in reducing the abundance and size of epizoans on cultivated Fucus biomass. A second question was if regular desiccation affects the growth rate of cultivated thalli. The results show that growth rate as well as epizoan size and number are influenced by regular desiccation and that choosing the right desiccation regime allows for cultivation at growth rates comparable to non-desiccated cultures, but with significantly less epizoan biomass and abundance. In the following 
sections, the effects on Fucus growth and epizoan size and abundance will be discussed separately.

\section{Fucus growth}

The results clearly demonstrate individual differences between the two Fucus species with respect to survival and growth performance under desiccation conditions. Fucus vesiculosus generally showed significantly higher growth rates (control: $3.27 \%$ day $^{-1}$ ) than $F$. serratus (control: $2.12 \%$ day $^{-1}$ ), which corresponds with data of our other cultivation experiments (Meichssner et al. in prep.).

Fucus vesiculosus appeared to be extremely tolerant to desiccation and was able to maintain considerable growth rates at weekly desiccations to $40 \%$ of its ww. This is not surprising as this species is adapted to intertidal habitats with regular desiccation (Schonbeck and Norton 1978; Andreev et al. 2012). However, the Baltic Sea populations are only subject to irregular desiccations caused by wind driven sea level changes (pseudo-tidal) and show some adaptation towards lower desiccation resistance compared with e.g. North Sea individuals (Pearson et al. 2000). Fucus serratus was less resistant than $F$. vesiculosus and degraded at desiccations to $60 \%$ of its ww (Schonbeck and Norton 1979a; Andreev et al. 2012). In the Baltic Sea, this species is air exposed only during extreme weather events. This is in contrast to the rest of its distributional range along North Atlantic coasts, where it forms a belt in the intertidal right below the $F$. vesiculosus belt and experiences desiccation on a daily basis (Schonbeck and Norton 1978; Contreras-Porcia et al. 2017). It seems that the Baltic Sea population has adapted or acclimated to a very low desiccation risk which has not been experimentally investigated as it has been for F. vesiculosus by Pearson et al. (2000).

If desiccation regimes applied in the course of the experiment were non-lethal (all but the $1 \times 60 \%$ treatment for $F$. serratus which was replaced by $3 \times 90 \%$ ), the effects on the growth rates were very small. Only the harsh treatments $(1 \times 40 \%, 1 \times 60 \%)$ applied to $F$. vesiculosus yielded a statistically significant reduction of the growth rate when compared with the control. All other treatments did not result in statistically significant growth reductions compared with their respective control within the 7-week period. Given these results, there seems to be a species-specific threshold of desiccation intensity (percentage of ww desiccated to), below which the thalli die and above which the growth is only slightly impacted, either by minor damages of the metabolism which can be repaired on little costs with respect to growth, or by a slight reduction of the metabolism. Generally, this result supports the applicability of this method for aquacultural purposes. It is also in line with Schramm (1968), who found that Baltic Sea $F$. vesiculosus thalli desiccated to $60 \%$ and $30 \%$ of ww show very similar relative assimilation rates over time (indicating similar growth rates) while thalli desiccated to less than $30 \%$ of ww show reduced assimilation rates and die after some days. Thus, the threshold seems to lie at about $30 \%$ of ww for $F$. vesiculosus. For Baltic Sea $F$. serratus, the threshold is not exactly known, but based on our results, it seems to lie above $60 \%$ of ww.

The air temperature during desiccation may also affect survival and growth of Fucus thalli (Brinkhuis et al. 1976; Quadir et al. 1979; Gylle et al. 2009). However, as the temperatures during the desiccations were more or less equal for all treatments, we assume that the observed effects on Fucus growth resulted from the degree of desiccation rather than the air temperature during desiccation. The data of Schramm (1968), who could show that only air temperatures above $30{ }^{\circ} \mathrm{C}$ impact $F$. vesiculosus survival and that photosynthesis rates of thalli at different moderate desiccation regimes are similar at temperatures below $30{ }^{\circ} \mathrm{C}$ (which reflects the conditions during our experiment), confirm this assumption (but see Gylle et al. 2009).

The factor season (and hence water temperature, light conditions, and nutrient concentrations) may also impact the desiccation tolerance (Davison and Pearson 1996). Schonbeck and Norton (1979a, b) found higher desiccation tolerance in summer than in winter for $F$. spiralis (see also Haring et al. 2002), yet this has not been investigated for Baltic Sea $F$. vesiculosus and $F$. serratus. Another factor worth investigating in the cultivated Fucus species is drought-hardening, i.e. the increased tolerance due to frequent desiccations (Schonbeck and Norton 1979a, b), which was also not within the scope of this study.

Summarizing the effect of desiccation on the growth rate of cultivated Fucus thalli, it can be stated that non-lethal regimes reduce growth rates only slightly which allows for the aquacultural use of these regimes.

The appropriate desiccation levels, however, have to be determined for every cultivated species and/or population individually.

\section{Epizoans}

In most cases, the desiccation treatments led to significant reductions of epizoan weight as well as epizoan abundance. In this context, the effects on the epizoan weight reflect their growth after they have successfully settled, metamorphosized, and developed on the thalli, while the effects on the abundance reflect the initial larval settlement success and subsequent survival.

The weights of E. pilosa and A. improvisus were significantly reduced by all desiccation treatments, the bivalve weight was also visibly reduced but not to the same extent as in the other two epizoans and statistically not significant. The strongest effect was observed on the size of E. pilos $a$; the colonies in the $1 \times 40 \%$ and the $3 \times 80 \%$ treatment (F. vesiculosus) consisted of less than 50 zooids while 
colonies in the control treatment had areas of several $\mathrm{cm}^{2}$, consisting of hundreds of zooids.

In contrast to the other two epizoans, which are colonizing intertidal locations in the Atlantic and pseudo-tidal locations in the Baltic Sea, E. pilosa is a low inter- to subtidal species (Yorke and Metaxas 2011) and hence less resistant to desiccation. This was also clearly visible in the abundance data, where the strongest effects of desiccation were observed on E. pilosa. Especially the harsh treatments $(F$. vesiculosus: $1 \times$ $60 \%, 1 \times 40 \%$ ) reduced the number drastically, in case of $1 \times$ $40 \%$ even to zero. However, for E. pilosa even mild desiccations seem to be critical for survival, since no significant differences were observed between the different desiccation treatments.

The bivalves were equally affected by intensity and frequency of the desiccation, albeit their overall susceptibility was lower than that of the other two groups. Like A. improvisus, the bivalves seem to be most susceptible in the early settlement phase and therefore their number was successfully reduced by frequent desiccations. At the same time, harsh desiccations seem to be lethal even some days after settlement, visible by significantly less individuals in the $F$. vesiculosus $1 \times 40 \%$ treatment than in the $1 \times 80 \%$ treatment, which conforms to data of Jenewein and Gosselin (2013).

The abundance of $A$. improvisus was significantly more reduced by frequent mild desiccations than by single harsh desiccations, indicating that only the settling cypris larvae and possibly the early post-metamorphic stages of this species are intolerant to desiccation (Foster 1971a; Essock-Burns et al. 2017). In most of the cases, frequent desiccations every 2 3 days, as in the $3 \times 80 \%$ (F. vesiculosus) and the $3 \times 90 \%$ (F. serratus) treatment, did probably not allow for the sufficient development of structures necessary for desiccation resistance. Single desiccations per week seem to offer enough time for the formation of these structures; the developing adult stages were then able to survive even harsh desiccation treatments.

Epiphytes were scarce on the thalli in our experiment, because their biomass peak on Baltic Sea Fucus thalli is in spring (Rickert et al. 2015). Generally, we chose to study the effect of desiccation on epizoans and not on epiphytes, because epiphytes usually disappear after their growth period from the cultivated biomass and thus, despite their negative impact on Fucus growth (Rohde et al. 2008), do not have harmful effects on the quality of the biomass. Epizoans, by contrast, remain on the thalli once they have settled and thus drastically lower the quality and usability of the biomass. Our cultivation trials have shown that epiphytism is only a temporary problem while epizoans jeopardize the entire cultivation outcome.

Periodic air exposure and the concomitant desiccation are a determining factor for the distribution of species at intertidal locations (e.g. Foster 1971b; Boese et al. 2005). If the physiological desiccation resistance of the algal host and the epibiont are not equal, desiccation affects the colonization of the algal host. The data presented here underline this fact and show that this principle can be used in the aquaculture of Fucus species in order to reduce the amount of epizoans. Most successful are frequent mild desiccations because they only cause minor growth rate reductions of the cultivated thalli and at the same time have a strongly reducing effect on the weight and abundance of epizoans. Three desiccations to $80 \%$ of ww reduced the epizoan share of the total harvest of F. vesiculosus from 13.0 to $1.8 \%$, while the thallus growth rate was not significantly impacted. The resulting pure $F$. vesiculosus biomass (calculated as epizoan-free) was therefore higher in the $3 \times 80 \%$ treatment than in the control (although the difference was not significant). For $F$. serratus, the epizoan share of the harvest was even reduced from $19.0 \%$ in the control to $1.0 \%$ in the $3 \times 90 \%$ treatment. Here, the observed differences in the initial growth rate also disappeared in the final weight. These results indicate that the high epizoan load in the controls reduced their growth rates during the last month of the experiment leading to equal final weights at the end of the experiment despite of unequal initial growth rates. Considering these results, desiccation is absolutely necessary in order to maintain maximal growth rates and produce biomass which shows little epizoan colonization and is thus ready for market demands.

Of course, desiccation is not the only abiotic factor determining the amount of epizoans on seaweed thalli. Drag enforced by water motion does also influence the number of successfully settling epizoan larvae (Koehl 2007). In our culture system, the drag forces were almost zero, because the thalli were freely floating and hence able to move with the waves. This may explain the very high abundance of epizoans on the control thalli when compared with local field populations of $F$. vesiculosus and $F$. serratus that grow permanently submerged and show only very little epizoan colonization (Rickert et al. 2015). These populations grow attached by a holdfast, thus each water motion exerts drag forces on objects at the thallus surface possibly dislodging settling larvae.

Due to the absence of strong wave activity in the cultivation baskets, the whiplash effect, i.e. the process by which thalli by "continuous movement $[\ldots]$ clean the adjacent $[\ldots]$ surface and their own surface" (Kiirikki 1996), was also absent, which may have added to the striking difference between culture and field populations.

Apart from abiotic factors, biotic interactions play a crucial role in the colonization of seaweed thalli (e.g. Wahl and Hay 1995; Karez et al. 2000; Wahl et al. 2010). An important difference between the local field populations and the culture populations was that the snail Littorina littorea, which is very abundant in the field, was absent in the culture baskets. This snail efficiently grazes and/or bulldozes the epifauna and epiflora at the surface of Fucus thalli, probably removing a 
huge proportion of settling epizoan larvae (Lubchenco 1983; Watson and Norton 1985; Buschmann 2000). This "cleaning" did not happen in our experiment.

Additionally, the seaweeds and/or associated bacteria produce substances, e.g. diterpenes or phlorotannins, which reduce larval settlement (da Gama et al. 2014; Rickert et al. 2015). At the same time, some epizoans have preferences for specific host species in response to their respective surface chemistry (Matson et al. 2010; Denley et al. 2014). Differences in this anti-fouling/preference interaction may explain the significantly higher abundance of $A$. improvisus and E. pilosa on $F$. serratus controls compared with $F$. vesiculosus controls. For $E$. pilosa, neither data on anti-fouling activity by Fucus species nor data on preference behavior of the cyphonautes larvae are published. Yet, both Fucus species are known to produce phlorotannins against the settlement of A. improvisus (Brock et al. 2007). In the study of Rickert et al. (2015), the deterring effect of $F$. serratus surface extracts against $A$. improvisus settlement was stronger than the effect of $F$. vesiculosus surface extracts, which contradicts the results of our experiment. However, the same authors could not find a stringent connection between anti-fouling activity of surface extracts and realized fouling community on the thalli.

Therefore, anti-fouling activity and/or choice behavior could still be an explanation for the huge differences between the colonization of the $F$. vesiculosus and the $F$. serratus control. In general, the influence of the culture conditions of our experiment, as well as the effect of the desiccation regimes on this complex interaction system, is unclear.

From the results presented here, only the effect of the abiotic factor desiccation can be inferred and it remains unclear if this factor acts directly on the epizoans and/or also indirectly via an impact on biotic interactions. However, for the aquacultural application, the actual effect is of greater interest than its precise origin.

\section{Practical issues}

In this experiment, the cultivated biomass was desiccated to the targeted percentage of ww by regular weighing. This is of course not possible in large-scale aquaculture. Therefore, it is necessary to experimentally examine the evaporation of water from the cultivated thalli depending on the vapor pressure deficits that occur under the air temperature, air humidity, and wind conditions present at the cultivation site and can be calculated from those. Once these values have been determined, desiccation times can then be chosen according to the current or forecasted weather conditions. In this experiment, the thalli were desiccated in the shadow of an awning to avoid strong desiccation differences due to microclimatic differences between sun-exposed and shaded thalli. Of course, large aquaculture facilities can hardly be overshadowed by an awning; therefore, desiccation during the night may be a suitable alternative having also the advantage of less extreme temperature fluctuations and thus more predictable desiccation conditions.

\section{Conclusion and outlook}

The results clearly demonstrate that regular desiccation by air exposure reduces the amount of epizoans on cultivated Fucus biomass, on F. vesiculosus, and on $F$. serratus. At the same time, the applied desiccation regimes did not lower the growth rates significantly or at least not to levels unacceptable for cultivation purposes. We therefore conclude that the tested approach can be used as an effective measure to reduce epizoan fouling in Fucus aquaculture. In this study, we of course only tested the biological basics; a technically feasible large-scale solution for the implementation of this method in a Fucus farm was not the aim of this study and requires further development. One possible solution would be the regular elevation of net cages by inflatable floating bodies installed below the cages. The positive effects of desiccation on the fouling of the thalli found in this study can be equally expected on cage and other installation material used in an aquaculture farm. Therefore, a full emersion of entire cages would not only be practical but also beneficial for the cleanliness and thus the water permeability of the cages. During the experiment presented here, no grazing marks were observed on the thalli; however, amphipods, isopods, and snails are usually present in the cultivation baskets and may cause severe biomass losses in Fucus aquaculture. As at least amphipods and isopods are very susceptible to desiccation, the emersion of entire cages would probably also be an effective means to reduce grazing pressure in commercial cultures.

Acknowledgements Open Access funding enabled and organized by Projekt DEAL. The authors want to thank Kieler Meeresfarm GmbH \& Co. KG for providing their facilities, helpful advices concerning practical issues, and protection of the experiment during storm events. The authors owe particular thanks to Florian Weinberger for fruitful discussions on the study outline and data analysis, Frauke Pescheck for providing light data for the time of the experiment, and Ruth Gingold for language correction.

Author contributions Rafael Meichssner was responsible for the concept and design of the study, assisted and supervised all experimental work, performed the data analysis, and wrote the first draft of the manuscript. Rüdiger Schulz supervised and supported the study conceptualization and the data analysis. Peter Krost assisted in the study conceptualization and the practical experimental design. RS and PK reviewed and edited the first draft of the manuscript. Anna-Sarah Cosin performed the essential pre- experiments in 2018. Nadja Stegmann performed Fucus growth measurements, Dagobert Sachs and Matthias 
Bressan performed epizoan quantification and Henriette Marx performed the weight determination of epizoans. All authors read and approved the final manuscript.

Funding The study was funded by Studienstiftung des Deutschen Volkes, Fazit- Stiftung, and the InterReg-Deutschland-Denmark project FucoSan.

\section{Compliance with ethical standards}

Conflict of interest The authors declare that they have no conflict of interest.

Open Access This article is licensed under a Creative Commons Attribution 4.0 International License, which permits use, sharing, adaptation, distribution and reproduction in any medium or format, as long as you give appropriate credit to the original author(s) and the source, provide a link to the Creative Commons licence, and indicate if changes were made. The images or other third party material in this article are included in the article's Creative Commons licence, unless indicated otherwise in a credit line to the material. If material is not included in the article's Creative Commons licence and your intended use is not permitted by statutory regulation or exceeds the permitted use, you will need to obtain permission directly from the copyright holder. To view a copy of this licence, visit http://creativecommons.org/licenses/by/4.0/.

\section{References}

Anderson LM, Martone PT (2014) Biomechanical consequences of epiphytism in intertidal macroalgae. J Exp Biol 217:1167-1174

Anderson RJ, Levitt GJ, Share A (1996) Experimental investigation for the mariculture of Gracilaria in Saldanha Bay, South Africa. J Appl Phycol 8:421-430

Andreev VP, Maslov YI, Sorokoletova EF (2012) Functional properties of photosynthetic apparatus in three Fucus species inhabiting the White Sea: effect of dehydration. Russ J Plant Physl 59:217-223

Bannister J, Sievers M, Bush F, Bloecher N (2019) Biofouling in marine aquaculture: a review of recent research and developments. Biofouling 35:631-648

Barnes H, Barnes M (1957) Resistance to desiccation in intertidal barnacles. Science 126:358

Boese BL, Robbins BD, Thursby G (2005) Desiccation is a limiting factor for eelgrass (Zostera marina $\mathrm{L}$.) distribution in the intertidal zone of a northeastern Pacific (USA) estuary. Bot Mar 48:274-283

Brinkhuis BH, Temple NR, Jones RF (1976) Photosynthesis and respiration of exposed salt-marsh fucoids. Mar Biol 34:349-359

Brock E, Nylung GM, Pavia H (2007) Chemical inhibition of barnacle larval settlement by the brown alga Fucus vesiculosus. Mar Ecol Prog Ser 337:165-174

Bruhn A, Tørring DB, Thomsen M, Canal-Verges P, Nielsen MM, Rasmussen MB, Eybye KL, Larsen MM, Balsby TJS, Petersen JK (2016) Impact of environmental conditions on biomass yield, quality, and bio-mitigation capacity of Saccharina latissima. Aquacult Environ Interact 8:619-636

Bundesamt für Naturschutz (2013) Rote Liste gefährdeter Tiere, Pflanzen und Pilze Deutschlands, Band 2: Meeresorganismen. BfNSchriftenvertrieb, Bonn

Buschbaum C, Saier B (2001) Growth of the mussel Mytilus edulis L. in the Wadden Sea affected by tidal emergence and barnacle epibionts. J Sea Res 45:27-36
Buschmann C (2000) Direct and indirect effects of Littorina littorea (L.) on barnacles growing on mussel beds in the Wadden Sea. Hydrobiologia 440:119-128

Buschmann AH, Gomez P (1993) Interaction mechanisms between Gracilaria chilensis (Rhodophyta) and epiphytes. Hydrobiologia 260:345-351

Cherry P, O’Hara C, Magee PJ, McSorley EM, Allsopp PJ (2019) Risks and benefits of consuming edible seaweeds. Nutr Rev 77:307-329

Contreras-Porcia L, Lopez-Cristoffanini C, Maynard A, Kumar M (2017) Tolerance pathways to desiccation stress in seaweeds. In: Kumar M, Ralph P (eds) Systems biology of marine ecosystems. Springer, Heidelberg, pp 13-33

da Gama BAP, Plouguerné E, Pereira RC (2014) The antifouling defence mechanisms of marine macroalgae. Adv Bot Res 71:413-440

Davison IR, Pearson GA (1996) Stress tolerance in intertidal seaweeds. J Phycol 32:197-211

Denley D, Metaxas A, Short J (2014) Selective settlement by larvae of Membranipora membranacea and Electra pilosa (Ectoprocta) along kelp blades in Nova Scotia, Canada. Aquat Biol 21:47-56

Dring MJ, Brown FA (1982) Photosynthesis of intertidal brown algae during and after periods of emersion: a renewed search for physiological causes of zonation. Mar Ecol Prog Ser 8:301-308

Essock-Burns T, Gohad NV, Orihuela B, Mount AS, Spillmann CM, Wahl KJ, Ritschof D (2017) Barnacle biology before, during and after settlement and metamorphosis: a study of the interface. J Exp Biol 220:194-207

FAO (2018a) The State of World Fisheries and Aquaculture 2018 Meeting the sustainable development goals. Rome, pp 17-30

FAO (2018b) The global state of seaweed production, trade and utilization. Globefish Research Programme Volume 124. Rome, pp 1-120

Fletcher RL (1995) Epiphytism and fouling in Gracilaria cultivation: an overview. J Appl Phycol 7:325-333

Førde H, Forbord S, Handå A, Fossberg J, Arff J, Johnsen G, Reitan KI (2016) Development of bryozoan fouling on cultivated kelp (Saccharina latissima) in Norway. J Appl Phycol 28:1225-1234

Foster BA (1971a) Desiccation as a factor in the intertidal zonation of barnacles. Mar Biol 8:12-29

Foster BA (1971b) On the determinants of the upper limit of intertidal distribution of barnacles (Crustacea: Cirripedia). J Anim Ecol 40: $33-48$

Gylle AM, Nygård CA, Ekelund GA (2009) Desiccation and salinity effects on marine and brackish Fucus vesiculosus L. (Phaeophyceae). Phycologia 48:156-164

Haglund K, Pedersen M (1988) Spray cultivation of seaweeds in recirculating brackish water. Aquaculture 72:181-189

Haring RN, Dethier MN, Williams SL (2002) Desiccation facilitates wave-induced mortality of the intertidal alga Fucus gardneri. Mar Ecol Prog Ser 232:75-82

Hayashi L, Hurtado AQ, Msuya FE, Bleicher-Lhonneur G, Critchley AT (2010) A review of Kappaphycus farming: prospects and constraints. In: Israel A, Einav R, Seckbach J (eds) Seaweeds and their role in globally changing environments. Springer, Heidelberg, pp 255-283

Hurtado AQ, Critchley AT, Trespoey A, Lhonneur GB (2006) Occurrence of Polysiphonia epiphytes in Kappaphycus farms at Calaguas Is., Camarines Norte, Phillippines. J Appl Phycol 18: 301-306

Jenewein BT, Gosselin LA (2013) Ontogenetic shift in stress tolerance thresholds of Mytilus trossulus: effects of desiccation and heat on juvenile mortality. Mar Ecol Prog Ser 481:147-159

Karez R, Engelbert S, Sommer U (2000) Co-consumption and protective coating: two new proposed effects of epiphytes on their macroalgal hosts in mesograzer-epiphyte-host interactions. Mar Ecol Prog Ser 205:85-93 
Kasim M, Jamil MR, Irawati N (2017) Occurrence of macro-epiphyte on Eucheuma spinosum cultivated on floating cages. Aquac Aquar Conserv Legis 10:633-639

Kautsky N, Kautsky H, Kautsky U, Waern M (1986) Decreased depth penetration of Fucus vesiculosus (L.) since the 1940s indicates eutrophication of the Baltic Sea. Mar Ecol Prog Ser 28:1-8

Kiirikki M (1996) Experimental evidence that Fucus vesiculosus (Phaeophyta) controls filamentous algae by means of the whiplash effect. Eur J Phycol 31:61-66

Kim GH, Moon KH, Kim JY, Shim J, Klochkova TA (2014) A revaluation of algal diseases in Korean Pyropia (Porphyra) sea farms and their economic impact. Algae 29:249-265

Kim JK, Yarish C, Hwang EK, Park M, Kim M (2017) Seaweed aquaculture: cultivation technologies, challenges and its ecosystem services. Algae 32:1-13

Koehl MRA (2007) Mini review: hydrodynamics of larval settlement into fouling communities. Biofouling 23:357-368

Lehvo A, Bäck S, Kiirikki M (2001) Growth of Fucus vesiculosus L. (Phaeophyta) in the northern Baltic proper: energy and nitrogen storage in seasonal environment. Bot Mar 44:345-350

Lubchenco J (1983) Littorina and Fucus: effects of herbivores, substratum heterogeneity, and plant escapes during succession. Ecology 64:1116-1123

Luther G (1987) Seepocken der deutschen Küstengewässer. Helgol Meeresunters 41:1-43

Mac Monagail M, Cornish L, Morrison L, Araujo R, Critchley AT (2017) Sustainable harvesting of wild seaweed resources. Eur J Phycol 52: 371-390

Matson PG, Steffen BT, Allen R (2010) Settlement behavior of cyphonautes larvae of the bryozoan Membranipora membranacea in response to two algal substrata. Invertebr Biol 129:277-283

Mumford TF, Miura A (1988) Porphyra as food: cultivation and economics. In: Lembi CA, Waaland JR (eds) Algae and human affairs. Cambridge University Press, Cambridge, pp 87-117

Park SC, Hwang EK (2012) Seasonality of epiphytic development of the hydroid Obelia geniculata on cultivated Saccharina japonica (Laminariaceae, Phaeophyta) in Korea. J Appl Phycol 24:433-439

Pearson G, Kautsky L, Serrão E (2000) Recent evolution in Baltic Fucus vesiculosus: reduced tolerance to emersion stresses compared to intertidal (North Sea) populations. Mar Ecol Prog Ser 202:67-79

Pescheck F, Bilger W (2019) High impact of seasonal temperature changes on acclimation of photoprotection and radiation-induced damage in field grown Arabidopsis thaliana. Plant Physiol Biochem 134: $129-136$

Quadir A, Harrison PJ, DeWreede RE (1979) The effects of emergence on the photosynthesis and respiration of marine macrophytes. Phycologia 18:83-88

R Core Team (2013) R: a language and environment for statistical computing. R Foundation for Statistical Computing, Vienna. http:// www.R-project.org/. Accessed 19 Oct 2019
Rickert E, Karsten U, Pohnert G, Wahl M (2015) Seasonal fluctuations in chemical defenses against macrofouling in Fucus vesiculosus and Fucus serratus from the Baltic Sea. Biofouling 31:363-377

Rohde S, Hiebenthal C, Wahl M, Karez R, Bischof K (2008) Decreased depth distribution of Fucus vesiculosus (Phaeophyceae) in the Western Baltic: effects of light deficiency and epibionts on growth and photosynthesis. Eur J Phycol 43:143-150

Rolin C, Inkster R, Laing J, McEvoy L (2017) Regrowth and biofouling in two species of cultivated kelp in the Shetland Islands, UK (2017). J Appl Phycol 29:2351-2361

Sand-Jensen K, Revsbech NP (1987) Photosynthesis and light adaptation in epiphyte-macrophyte associations measured by oxygen microelectrodes. Limnol Oceanogr 32:452-457

Schonbeck M, Norton TA (1978) Factors controlling the upper limits of fucoid algae on the shore. J Exp Mar Biol Ecol 31:303-313

Schonbeck M, Norton TA (1979a) The effects of brief periodic submergence on intertidal fucoid algae. Estuar Coast Mar Sci 8:205-211

Schonbeck M, Norton TA (1979b) Drought-hardening in the upper-shore seaweeds Fucus spiralis and Pelvetia canaliculata. J Ecol 67:787796

Schramm W (1968) Ökologisch-physiologische Untersuchungen zur Austrocknungs- und Temperaturresistenz an Fucus vesiculosus L. der westlichen Ostsee. Int Rev Gesamten Hydrobiol 53:469-510

Torn K, Krause-Jensen D, Martin G (2006) Present and past depth distribution of bladder wrack (Fucus vesiculosus) in the Baltic Sea. Aquat Bot 84:53-62

Utermann C, Parrot D, Breusing C, Stuckas H, Staufenberger T, Blümel M, Labes A, Tasdemir D (2018) Combined genotyping, microbial diversity and metabolite profiling studies on farmed Mytilus spp. from Kiel Fjord. Sci Rep 8:7983

Wahl M (1989) Marine epibiosis. I. Fouling and antifouling: some basic aspects. Mar Ecol Prog Ser 58:175-189

Wahl M, Hay ME (1995) Associational resistance and shared doom effects of epibiosis on herbivory. Oecologia 102:329-340

Wahl M, Shahnaz L, Dobretsov S, Saha M, Symanowski F, David K, Lachnit T, Vasel M, Weinberger F (2010) Ecology of antifouling resistance in the bladder wrack Fucus vesiculosus: patterns of microfouling and antimicrobial protection. Mar Ecol Prog Ser 411: $33-48$

Walls AM, Edwards MD, Firth LB, Johnson MP (2017) Successional changes of epibiont fouling communities of the cultivated kelp Alaria esculenta: predictability and influences. Aquacult Environ Interact 9:55-69

Watson DC, Norton AT (1985) Dietary preferences of the common periwinkle, Littorina littorea (L.). J Exp Mar Biol Ecol 88:193-211

Yorke AF, Metaxas A (2011) Interactions between an invasive and a native bryozoan (Membranipora membranacea and Electra pilosa) species on kelp and Fucus subtrates in Nova Scotia, Canada. Mar Biol 158:2299-2311

Publisher's note Springer Nature remains neutral with regard to jurisdictional claims in published maps and institutional affiliations. 